\title{
Investigation of the Relationship between Free Time Management, Social Media Addiction and Life Satisfaction of University Students During the COVID-19 Pandemic Process
}

\author{
Recep Cengiz \\ Faculty of Sport Sciences, Manisa Celal Bayar University, Manisa, Turkey \\ E-mail: rcengiz1965@gmail.com \\ Batuhan Er (Corresponding author) \\ Faculty of Sport Sciences, Istanbul Gedik University, Istanbul, Turkey \\ E-mail: batuhaner32@hotmail.com
}

Received: November 5, 2021 Accepted: December 5, 2021

Published: December 31, 2021

doi:10.5296/jei.v7i3.19149 URL: https://doi.org/10.5296/jei.v7i3.19149

\begin{abstract}
The aim of this study is to examine the relationship between university students free time management, social media addiction and life satisfaction during the COVID-19 pandemic.

The sample group of the study consists of 114 female and 291 male university students. Free Time Management Scale, Social Media Addiction Scale and Life Satisfaction Scale were used as data collection instruments in the research. SPSS 25 package program was used in the analysis of the data; In their statistical representations, arithmetic mean, standard deviation and frequency values are presented. For analysis to the data set; T-Test for Independent Samples, Multivariate Analysis of Variance (MANOVA), One Way Analysis of Variance (ANOVA) and Pearson Correlation Test were applied.

When the T-Test results for Independent Samples are examined; In terms of gender variable, a significant difference was found in favor of women in the "goal setting and method" sub-dimension of the Free Time Management Scale. When the results of Multivariate Analysis of Variance MANOVA test were examined; In terms of daily social media usage
\end{abstract}


times, a significant difference was found in the sub-dimensions of preoccupation, mood regulation, repetition and conflict of the Social Media Addiction Scale.

As a result, it is seen that there is a relationship between university student participants' free time management and social media addiction. However, no relationship was found between life satisfaction and social media addiction. While a low negative correlation was found between the total score of life satisfaction and the free time management programming sub-dimension, no correlation was found between the sub-dimensions of goal determination and method, assessment and free time attitude.

Keywords: Free time management, Social media addiction, Life satisfaction

\section{Introduction}

In recent years, that can be said that there is an important relationship between the increasing importance of free time management of individuals and societies and the level of satisfaction that may arise in line with the efficiency of this management in human life, which has become significantly digitalized with the global development of technology and internet infrastructures. It can be seen that in the global epidemic period, which has affected the whole world in 2020 and called the "COVID-19 Pandemic", individuals and societies spend a significant part of their time in certain areas due to the restrictions in their fight against this situation. The fact that individuals and societies intensify their use of the internet and social media in the digital world, and the fact that they can easily reach the things they aim to achieve, brings with it certain question marks about the concepts of free time management, social media addiction and life satisfaction, and therefore a need for research.

\section{Literature Review}

Wang et al. (2011) points out the stages of "determining goals and priorities, techniques for managing free time, choosing organization and programming, and attitudes towards free time" for the concept of free time management. However, it can be stated that individuals who manage their spare time well have a better quality of life. Wang (2019), on the other hand, states that a bad free time management indirectly affects internet addiction together with free time boredom.

It is known that as of January 2021, 4.66 billion individuals in the world are active social media users and this statistic constitutes $59.5 \%$ of the total world population. It is seen that $92.6 \%$ of these users ( 4.32 billion people) access the internet and social media via mobile devices. However, it is stated that the daily social media usage time per person, which was 142 minutes worldwide in 2019, reached 145 minutes by 2020 (Statista, 2021). Zivnuska et al. (2019) defines social media addiction as "excessive use and habitual following of social media, manifesting itself with compulsive use at the expense of other activities". It is stated that social media can cause behavioral addiction at a level that can hinder daily functioning and productivity. Griffiths and Kuss (2017), on the other hand, address the issue from a different perspective, especially for certain age groups, not what social media does today, but who it means, and states that social media platforms can be accepted as a way of existence. While research shows that many individuals are engaged in social media, these individuals 
can also use social media platforms for very different purposes. For example; Instagram, which allows sharing of photos and videos by combining similar interests and groups; LinkedIn for individuals who want to have a profile in their career field and are looking for a new job; or social media networks such as Youtube and Facebook, which contain different content, can facilitate individuals' access to the goals they want to achieve. In general, it can be said that a significant majority of individuals stay online longer than they intended, and this affects their general life patterns such as sleep and work productivity, and in some cases, they prefer to communicate with other individuals over social media and the internet instead of face-to-face interaction (Nakaya, 2015). This situation may also raise important question marks in terms of the efficiency of individuals' free time management. Grau et al. (2019) discussed social media addiction among university students and stated that with the increasing number of users on many social media platforms, a significant amount of time can be spent on these activities. On the other hand, Cömlekci and Basol (2019) in their study to examine the relationship between young people's social media usage purposes and social media addiction; they reveal a positive relationship between social media addiction and free time assessment. It is emphasized that the addiction level of young people who frequently use social media for free time assessment purposes has increased.

In the concept of life satisfaction, the degree to which the individual evaluates the general quality of individuals life as a whole or the degree of liking the life she lives is emphasized (Veenhoven, 1996). With the concept of life satisfaction, a cognitive judgment process is specified and the evaluation of the quality of the person according to the criteria individuals chooses is expressed (Diener et al., 1985). Sahin (2017) emphasizes that social media addiction is an important variable in predicting life satisfaction and states that university students have a significant negative impact on their life satisfaction. Hawi and Samaha (2016), on the other hand, argue that social media addiction does not have a direct effect on life satisfaction.

In this direction, the aim of the study is to examine the relationship between university students' free time management, social media addiction and life satisfaction during the COVID-19 pandemic. During the COVID-19 pandemic, individuals and societies have intensified their orientation to the use of digital world and social media. When the situation of being able to reach the things, the aims to achieve in an easy way is added to this; It has brought certain question marks about free time management, social media addiction and life satisfaction level. Therefore, this situation reflects the subjective aspect of the study, revealing the need for such a research.

\section{Method}

\subsection{Research Model}

In the study, descriptive and relational survey model, which is one of the quantitative research methods, was used.

\subsection{Study Sample}

The sample group of the study consisted of 114 female and 291 male (21.07 \pm 2.802$)$ 


\section{Macrothink}

university students, which were determined by the convenience sampling method (Coskun et al., 2017) due to its affordability and ease of reaching the participants.

\subsection{Data Collection Instruments}

Personal information form, Free Time Management Scale, Social Media Addiction Scale and Life Satisfaction Scale were used to collect data in the study.

Free Time Management Scale: The Original form was developed by Wang et al. (2011), the adaptation of the scale to Turkish culture was carried out by Akgul and Karakucuk (2015), and it consists of 15 items, 4 sub-dimensions and a 5-point Likert type structure. Sub-dimensions; goal determination and method, assessment, free time attitude and programming, the Likert structure is "1: I strongly disagree; 2: I do not agree; 3: I am undecided; 4: I agree; 5: I completely agree". While the items in the "programming" sub-dimension of the scale consisted of negative statements, the scoring was reversed.

Social Media Addiction Scale: The scale was developed by Tutgun Ünal (2015) to measure the social media addictions of university students and consists of 41 items, 4 sub-dimensions and a 5-point Likert type structure. Sub-dimensions; preoccupation, mood regulation, repetition, and conflict. Likert structure consists of expressions in the range of "never", "rarely", "sometimes", "often" and "always".

Life Satisfaction Scale: The original form was developed in Diener et al. (1985) The Life Satisfaction Scale consisting of 5 items and a single factor developed by Dagli and Baysal (2016) was adapted to Turkish culture. The rating of the scale, which has a 5-point Likert structure, is " 1 : I do not agree at all; 2: I agree very little; 3: I agree at a moderate level; 4: I agree strongly; 5: I completely agree". 
Table 1. Reliability test results for scales

\begin{tabular}{|c|c|c|c|}
\hline & & Original Study Reliability $(\alpha)$ & Current Study Reliability $(\alpha)$ \\
\hline \multirow{5}{*}{$\sum_{i}^{\infty}$} & Preoccupation & .93 & .94 \\
\hline & Mood Regulation & .89 & .93 \\
\hline & Repetition & .91 & .91 \\
\hline & Conflict & .95 & .96 \\
\hline & Social Media Addiction Scale Total & .96 & .96 \\
\hline \multirow{5}{*}{$\sum_{I}^{\infty}$} & Goal Determination and Method & .81 & .90 \\
\hline & Assessment & .79 & .83 \\
\hline & Free Time Attitude & .71 & .88 \\
\hline & Programming & .73 & .68 \\
\hline & Free Time Management Scale Total & .83 & .91 \\
\hline LSS & Life Satisfaction Scale & .88 & .89 \\
\hline
\end{tabular}

\subsection{Data Analysis}

SPSS 25 package program was used in the analysis of the data; In their statistical representations, arithmetic mean, standard deviation and frequency values are presented. In addition, T-Test for Independent Samples, Multivariate Analysis of Variance (MANOVA), One-Way Analysis of Variance (ANOVA) and Pearson Correlation Test were applied to the data set. 


\section{Findings}

\subsection{Findings Regarding the Demographic Characteristics of the Participants}

Table 2. Descriptive statistics on the demographic information of the participants

\begin{tabular}{|c|c|c|c|c|}
\hline Variables & Sub-Group & $\mathrm{N}$ & $\%$ & Total \\
\hline \multirow{2}{*}{ Gender } & Female & 114 & 28.1 & \multirow{19}{*}{405} \\
\hline & Male & 291 & 71.9 & \\
\hline \multirow{4}{*}{ Class } & $1 \mathrm{st}$ & 48 & 11.9 & \\
\hline & 2nd & 96 & 23.7 & \\
\hline & $3 \mathrm{rd}$ & 177 & 43.7 & \\
\hline & 4 th & 84 & 20.7 & \\
\hline \multirow{3}{*}{ Social Media Daily Usage Time } & $0-2$ hour & 99 & 24.4 & \\
\hline & $3-5$ hour & 234 & 57.8 & \\
\hline & 6 and above & 72 & 17.8 & \\
\hline \multirow{5}{*}{ Weekly Free Time Proficiency Level } & Absolutely not enough & 12 & 3.0 & \\
\hline & Not enough & 75 & 18.5 & \\
\hline & Normal & 138 & 34.1 & \\
\hline & Enough & 120 & 29.6 & \\
\hline & Definitely enough & 60 & 14.8 & \\
\hline \multirow{5}{*}{ Difficulty making use of free time or managing time } & Never & 24 & 5.9 & \\
\hline & Sometimes & 162 & 40.0 & \\
\hline & Rarely & 123 & 30.4 & \\
\hline & Often & 60 & 14.8 & \\
\hline & Always & 36 & 8.9 & \\
\hline
\end{tabular}

When the demographic information of the participants in Table 1 are examined; It is seen that $28.1 \%$ are women and $71.9 \%$ are men. In terms of class variable, it is seen that the most intense group consists of 3rd grade students with $43.7 \%$. It can be said that the variable of daily usage time of social media is distributed as " $3-5$ hours" with $57.8 \%$, " $0-2$ hours" with $24.4 \%$ and "6 hours and above" with $17.8 \%$. When the results are examined in terms of the weekly free time proficiency level of the participants, it is seen that the "normal" option is the highest with $34.1 \%$, and the option "absolutely insufficient" with $3 \%$ is the lowest preferred 


\section{Macrothink

answer. In terms of having difficulty in making use of free time or managing time, it is seen that $40 \%$ of the participants concentrate on the "sometimes" option and the lowest response is "never" with $5.9 \%$.

3.2 Findings Related to Free Time Management, Social Media Addiction and Life Satisfaction of the Participants

Table 3. t-Test results of Free Time Management Scale sub-dimensions by gender variable

\begin{tabular}{|c|c|c|c|c|c|c|c|}
\hline & Gender & $\mathrm{N}$ & $\bar{X}$ & Ss & $\mathrm{df}$ & $\mathrm{t}$ & $\mathrm{p}$ \\
\hline \multirow{2}{*}{ Goal Determination and Method } & Female & 114 & 3.0219 & 1.01622 & \multirow{2}{*}{403} & \multirow{2}{*}{2.370} & \multirow{2}{*}{$.018^{*}$} \\
\hline & Male & 291 & 2.7663 & .96002 & & & \\
\hline \multirow{2}{*}{ Assessment } & Female & 114 & 2.7632 & 1.16970 & \multirow{2}{*}{403} & \multirow{2}{*}{1.006} & \multirow{2}{*}{.315} \\
\hline & Male & 291 & 2.6426 & 1.04963 & & & \\
\hline \multirow{2}{*}{ Free Time Attitude } & Female & 114 & 2.4561 & 1.32465 & \multirow{2}{*}{403} & \multirow{2}{*}{.667} & \multirow{2}{*}{.505} \\
\hline & Male & 291 & 2.3608 & 1.28176 & & & \\
\hline \multirow{2}{*}{ Programming } & Female & 114 & 1.7895 & .59209 & \multirow{2}{*}{403} & \multirow{2}{*}{-1.140} & \multirow{2}{*}{.255} \\
\hline & Male & 291 & 1.8660 & .61338 & & & \\
\hline
\end{tabular}

Note. $* \mathrm{p}<.05$.

When the results of the T-Test for Independent Samples analysis were examined in terms of gender variable, a significant difference was found in the "goal determination and method" sub-dimension and it could be said that this significant difference was in favor of women ( $p$ $<.05$ ); no significant difference was found in the sub-dimensions of assessment, free time attitude and programming $(\mathrm{p}>.05)$. However, no significant difference was found in the sub-dimensions of SMAS and the total score of LSS in terms of the gender variable $(p>.05)$. 


\section{Macrothink}

Table 4. MANOVA test results regarding the daily social media usage time variable of the sub-dimensions of the Social Media Addiction Scale

\begin{tabular}{|c|c|c|c|c|c|c|c|}
\hline & Daily Social Media Usage Time & $\mathrm{N}$ & $\bar{X}$ & Ss & $\mathrm{F}$ & $\mathrm{p}$ & Difference \\
\hline \multirow{3}{*}{ Preoccupation } & $0-2$ hour & 99 & 2.0404 & .97440 & \multirow{3}{*}{76.661} & \multirow{3}{*}{.000} & A-B \\
\hline & 3-5 hour & 234 & 2.8184 & .79685 & & & A-C \\
\hline & 6 and above & 72 & 3.6007 & .63771 & & & B-C \\
\hline \multirow{3}{*}{ Mood Regulation } & $0-2$ hour & 99 & 1.8970 & 1.12753 & \multirow{3}{*}{32.032} & \multirow{3}{*}{.000} & A-B \\
\hline & $3-5$ hour & 234 & 2.5538 & 1.02447 & & & A-C \\
\hline & 6 and above & 72 & 3.2083 & 1.10997 & & & B-C \\
\hline \multirow{3}{*}{ Repetition } & 0-2 hour & 99 & 1.5333 & .78818 & \multirow{3}{*}{44.909} & \multirow{3}{*}{.000} & A-B \\
\hline & 3-5 hour & 234 & 2.1410 & .87900 & & & A-C \\
\hline & 6 and above & 72 & 2.8333 & 1.03461 & & & B-C \\
\hline \multirow{3}{*}{ Conflict } & 0-2 hour & 99 & 1.5630 & .72257 & \multirow{3}{*}{23.811} & \multirow{3}{*}{.000} & A-B \\
\hline & $3-5$ hour & 234 & 1.8664 & .79802 & & & A-C \\
\hline & 6 and above & 72 & 2.4167 & .91544 & & & B-C \\
\hline
\end{tabular}

Note. ${ }^{*} \mathrm{p}<.05$.

When the table is examined, as a result of the multivariate analysis of variance MANOVA test, the SMAS scale in terms of daily social media usage durations $(F=76.661 ; p<.05)$, mood regulation $(\mathrm{F}=32.032 ; \mathrm{p}<.05)$, repetition $(\mathrm{F}=44.409 ; \mathrm{p}<.05)$ and conflict $(\mathrm{F}=$ $23.881 ; \mathrm{p}<.05)$ sub-dimensions were found to be significantly different. In terms of daily social media use, there are differences in all sub-dimensions of SMAS, such as preoccupation, mood regulation, repetition, and conflict. It is seen that this difference is between the usage times of "0-2 hours and 3-5 hours", "0-2 hours and 6 hours and above" and "3-5 hours and 6 hours and above". 
Table 5. MANOVA test results regarding the daily free time management difficulty variable of the sub-dimensions of the Free Time Management Scale

\begin{tabular}{|c|c|c|c|c|c|c|c|}
\hline & Free Time Management Difficulty & $\mathrm{N}$ & $\bar{X}$ & Ss & $\mathrm{F}$ & $\mathrm{p}$ & Difference \\
\hline \multirow{5}{*}{ Goal Determination and Method } & Never & 24 & 2.0625 & 1.17318 & \multirow{5}{*}{11.882} & \multirow{5}{*}{.000} & $1-2$ \\
\hline & Sometimes & 162 & 2.6235 & .91354 & & & $1-3$ \\
\hline & Rarely & 123 & 3.0366 & 1.01996 & & & 1-7 \\
\hline & Often & 60 & 2.9500 & .82184 & & & $2-3$ \\
\hline & Always & 36 & 3.4583 & .65873 & & & $2-5$ \\
\hline \multirow{5}{*}{ Assessment } & Never & 24 & 2.3750 & 1.22104 & \multirow{5}{*}{14.543} & \multirow{5}{*}{.000} & $1-4$ \\
\hline & Sometimes & 162 & 2.4136 & .98631 & & & $1-5$ \\
\hline & Rarely & 123 & 2.5610 & 1.02012 & & & $2-4$ \\
\hline & Often & 60 & 3.2167 & .97584 & & & $3-4$ \\
\hline & Always & 36 & 3.5556 & 1.08086 & & & $3-5$ \\
\hline \multirow{5}{*}{ Free Time Attitude } & Never & 24 & 2.2083 & 1.52218 & \multirow{5}{*}{2.139} & \multirow{5}{*}{.075} & \multirow{5}{*}{-} \\
\hline & Sometimes & 162 & 2.1914 & 1.16648 & & & \\
\hline & Rarely & 123 & 2.5935 & 1.40357 & & & \\
\hline & Often & 60 & 2.5667 & 1.44230 & & & \\
\hline & Always & 36 & 2.3889 & .86005 & & & \\
\hline \multirow{5}{*}{ Programming } & Never & 24 & 1.5417 & .37831 & \multirow{5}{*}{5.798} & \multirow{5}{*}{.000} & \multirow{5}{*}{$\begin{array}{l}1-4 \\
1-5 \\
2-5 \\
3-5\end{array}$} \\
\hline & Sometimes & 162 & 1.7778 & .63049 & & & \\
\hline & Rarely & 123 & 1.8211 & .54871 & & & \\
\hline & Often & 60 & 2.0000 & .59185 & & & \\
\hline & Always & 36 & 2.1667 & .68313 & & & \\
\hline
\end{tabular}

Note. ${ }^{*} \mathrm{p}<.05$.

When the table is examined, as a result of the multivariate analysis of variance MANOVA test, FTMS goal determination and method $(\mathrm{F}=11.882 ; \mathrm{p}<.05)$, assessment $(\mathrm{F}=14.543 ; \mathrm{p}$ $<.05)$ and programming $(\mathrm{F}=5.798 ; \mathrm{p}<.05)$ sub-dimensions were found to be significantly different. The representation of these significant differences between groups is presented in the table. 
Table 6. Table of ANOVA tests related to some variables of Life Satisfaction Scale total score

\begin{tabular}{|c|c|c|c|c|c|c|c|c|c|c|c|}
\hline & & $\mathrm{N}$ & $\mathrm{X}$ & Ss & & $\begin{array}{l}\text { Sum of } \\
\text { Squares }\end{array}$ & sd & $\begin{array}{l}\text { Mean } \\
\text { Squares }\end{array}$ & $\mathrm{F}$ & $\mathrm{p}$ & Difference \\
\hline \multirow{4}{*}{ Class } & $1 \mathrm{st}$ & 48 & 3.2125 & .83478 & In group & 12.369 & 3 & 4.123 & \multirow{4}{*}{3.842} & \multirow{4}{*}{$.010^{*}$} & \multirow{4}{*}{$\begin{array}{l}1-4 \\
3-4\end{array}$} \\
\hline & 2 nd & 96 & 2.9188 & 1.05054 & Between Groups & 430.337 & 401 & 1.073 & & & \\
\hline & $3 \mathrm{rd}$ & 177 & 2.9695 & .96494 & Total & 442.706 & 404 & & & & \\
\hline & 4th & 84 & 2.6143 & 1.24602 & & & & & & & \\
\hline \multirow{3}{*}{$\begin{array}{l}\text { Social Media } \\
\text { Daily Usage }\end{array}$} & $0-2$ hour & 99 & 2.5939 & .98290 & In group & 36.156 & 2 & 18.078 & \multirow{3}{*}{17.876} & \multirow{3}{*}{$.000^{*}$} & \multirow{3}{*}{$\begin{array}{l}1-3 \\
2-3\end{array}$} \\
\hline & 3-5 hour & 234 & 2.8641 & 1.01820 & Between Groups & 406.550 & 402 & 1.011 & & & \\
\hline & 6 and more & 72 & 3.5083 & .99516 & Total & 442.706 & 404 & & & & \\
\hline \multirow{5}{*}{$\begin{array}{l}\text { Weekly Free Time } \\
\text { Proficiency Level }\end{array}$} & Absolutely not enough & 12 & 2.4000 & .73855 & In group & 9.459 & 4 & 2.365 & \multirow{5}{*}{2.183} & \multirow{5}{*}{.070} & \multirow{5}{*}{-} \\
\hline & Not enough & 75 & 2.8080 & 1.15100 & Between Groups & 433.246 & 400 & 1.083 & & & \\
\hline & Normal & 138 & 3.0174 & 1.02679 & Total & 442.706 & 404 & & & & \\
\hline & Enough & 120 & 3.0150 & 1.05166 & & & & & & & \\
\hline & Definitely enough & 60 & 2.7000 & .94922 & & & & & & & \\
\hline \multirow{5}{*}{$\begin{array}{l}\text { Difficulty making } \\
\text { use of free time } \\
\text { or managing time }\end{array}$} & Never & 24 & 3.2000 & 1.16021 & In group & 51.801 & 4 & 12.950 & \multirow{5}{*}{13.251} & \multirow{5}{*}{$.000^{*}$} & \multirow{5}{*}{$\begin{array}{l}1-4 \\
1-5 \\
2-4 \\
2-5 \\
3-4 \\
3-5\end{array}$} \\
\hline & Sometimes & 162 & 3.1852 & 1.02940 & Between Groups & 390.905 & 400 & .977 & & & \\
\hline & Rarely & 123 & 2.9707 & .94667 & Total & 442.706 & 404 & & & & \\
\hline & Often & 60 & 2.4200 & .85068 & & & & & & & \\
\hline & Always & 36 & 2.1167 & 1.03247 & & & & & & & \\
\hline
\end{tabular}

Note. ${ }^{*} \mathrm{p}<.05$.

When the results of the ANOVA test were examined in the table, a significant difference was found in terms of LSS total scores of the participants at different grade levels $(\mathrm{F}=3.842$; $\mathrm{p}$ $<.05)$. It is seen that this significant difference is between the 1 st and 4 th grades and between the 3rd and 4th grades. A significant difference was found in terms of LSS total scores in the daily use of social media by the participants $(\mathrm{F}=17.876 ; \mathrm{p}<.05)$. It can be said that this significant difference is seen as those who use social media between " $0-2$ hours and 3-5 hours" and between " $3-5$ hours and 6 hours and above". There was no significant difference in free time proficiency in terms of LSS total scores $(p>.05)$. A significant difference was found in terms of free time difficulties and LSS total scores $(F=13.251 ; p<.05)$. This significant difference is seen between the rating values shown in the table. 
Table 7. Pearson correlation test results for FTMS, SMAS, and LSS

\begin{tabular}{|l|l|l|l|l|l|l|}
\hline \multicolumn{2}{|l}{} & $\begin{array}{l}\text { Goal Determination } \\
\text { and Method }\end{array}$ & Assessment & Free Time Attitude & Programming & Life Satisfaction Total \\
\hline Preoccupation & $\mathrm{r}$ & $.281^{* *}$ & $.942^{* *}$ & $.147^{* *}$ & .091 & .034 \\
\hline Mood Regulation & $\mathrm{r}$ & $.274^{* *}$ & $.683^{* *}$ & $.190^{* *}$ & $.123^{*}$ & -.071 \\
\hline Repetition & $\mathrm{r}$ & $.220^{* *}$ & $.735^{* *}$ & $.226^{* *}$ & $.115^{*}$ & .070 \\
\hline Conflict & $\mathrm{r}$ & $.320^{* *}$ & $.616^{* *}$ & $.333^{* *}$ & $.212^{* *}$ & .055 \\
\hline Life Satisfaction Total & $\mathrm{r}$ & .066 & .016 & .047 & $-.157^{* *}$ & \\
\hline
\end{tabular}

Note. ${ }^{*} \mathrm{p}<.05$ and $* * \mathrm{p}<.01$.

When the results of Pearson Correlation Test were examined, it was found positively low relationship between that the SMAS preoccupation sub-dimension and the FTMS goal determination and method $(\mathrm{r}=.281)$, free time attitude $(\mathrm{r}=.147)$ sub-dimensions; In the assessment $(\mathrm{r}=.942)$ sub-dimension, a high level of positive correlation was found $(\mathrm{p}<.05)$. No relationship was found with the FTMS programming sub-dimension $(p>.05)$. SMAS mood regulation sub-dimension and FTMS goal determination and method $(\mathrm{r}=.274)$, free time attitude $(\mathrm{r}=.190)$ and programming $(\mathrm{r}=.123)$ sub-dimensions had positively low relationship; In the assessment $(\mathrm{r}=.683)$ sub-dimension, a high level of positive correlation was found $(\mathrm{p}<.05)$. There was a positive low relationship level between the SMAS repetition sub-dimension and the FTMS goal determination and method $(r=.220)$, free time attitude $(\mathrm{r}=.226)$ and programming $(\mathrm{r}=.115)$ sub-dimensions $(\mathrm{p}<.05)$. A high level of positive correlation was found with the assessment $(r=.735)$ sub-dimension $(p<.05)$. There was a low level of positive correlation between the SMAS conflict sub-dimension and the FTMS programming $(\mathrm{r}=.212)$ sub-dimension; A moderate positive correlation was found with the sub-dimensions of goal determination and method $(\mathrm{r}=.320)$ and free time attitude $(\mathrm{r}$ $=.333)$, and a high level of positive correlation with the assessment $(r=.616)$ sub-dimension $(\mathrm{p}<.05)$. While a low negative correlation was found between the total score of LSS and the FTMS programming $(r=.-157)$ sub-dimension, no correlation was found between the sub-dimensions of goal determination and method, assessment and free time attitude $(\mathrm{p}>.05)$. On the other hand, no correlation was found in the total score of LSS and SMAS sub-dimensions of preoccupation, mood regulation, repetition, and conflict $(p>.05)$.

\section{Discussion}

The results of this study, which was conducted to examine the relationship between free time management, social media addiction and life satisfaction of university students during the COVID-19 pandemic, are discussed in this section.

In terms of the gender variable of university students, a significant difference was found in the "goal determination and method" sub-dimension of the Free Time Management Scale; 
Serdar et al. (2017) similarly, they found a significant difference in the "goal determination and method" sub-dimension of the Free Time Management Scale. Contrary to this situation, Klerk and Bevan-Dye (2014) and Yasartürk et al. (2018), on the other hand, was not found any significant difference in the total score of free time management and its sub-dimensions in terms of gender variable.

While a significant difference was found in all sub-dimensions of the Social Media Addiction Scale in terms of the variable of daily use of social media by university students; Similarly, Aktan (2018) found a significant difference in the total score of the Social Media Addiction Scale and the sub-dimensions of preoccupation, mood regulation and repetition in terms of the variable of duration of daily social media use. Ciftci (2018), on the other hand, found a significant difference in the sub-dimensions of occupation and mood regulation.

It is seen that there is a significant difference in the variable of free time management difficulty of university students compared to free time management; Similarly, Kirtepe and Y1ldırım (2018) found a significant difference in the sub-dimensions of the Free Time Management Scale in terms of the free time management difficulty variable in their study.

Differences were found in life satisfaction of university students in terms of class, duration of social media use, weekly free time proficiency level and weekly free time management difficulties.

When the statistical test results are examined, it is seen that there is a positive relationship between university students' free time management and social media addiction; Yesildal and Ustunbaş (2019) found a low negative relationship between free time management and social media addiction. While a negative relationship was found only in the programming sub-dimension between free time management and life satisfaction; Kaas and Artimac (2017) similarly found a negative relationship between the programming sub-dimension of free time management and life satisfaction. Akgul et al. (2016) found a low positive correlation between all sub-dimensions of free time management and life satisfaction. However, no relationship was found between social media addiction and life satisfaction. Contrary to these results, Yesilyurt and Solpuk Turhan (2020) found a low negative relationship between social media addiction and life satisfaction in their study, while on behalf of university students, they suggested that as social media addiction attitudes increase, their life satisfaction decreases. Sahin (2017) similarly found a moderately negative relationship between social media addiction and life satisfaction. On the other hand, Longstreet and Brooks (2017) stated that individuals' life satisfaction is negatively related to social media addiction.

\section{Conclusion}

As a result, with this study, by examining the relationship between university students' free time management, social media addiction and life satisfaction during the COVID-19 pandemic; it is thought to shed light on the relationship between these concepts. The importance of revealing the relationship between the importance of free time management and the life satisfaction that individuals can obtain as a result of free time activities or personal preferences is known. When these time periods constitute important parts of the 
lives of individuals and when evaluated with productive outputs, positive results may arise for the development of certain groups of the society such as university students. In order to reveal the relationship between the mentioned concepts, the study can be carried out with different sample groups and different variables, and new results and suggestions can be put forward.

\section{References}

Akgül, B. M., \& Karaküçük, S. (2015). Free Time Management Scale: Validity and reliability analysis boş zaman yönetimi ölçeği: Geçerlik-güvenirlik çalışması. Journal of Human Sciences, 12(2), 1867-1880. https://doi.org/10.14687/ijhs.v12i2.3445

Akgül, B. M., Yenel, İ. F., \& Karaküçük, S. (2016). Evaluating free time management and its relation to life satisfaction, most participated leisure activities and gender among college students in Turkey. Social Sciences and Humanities Journal, 11(2), 2-18.

Aktan, E. (2018). Üniversite öğrencilerinin sosyal medya bağımlılık düzeylerinin çeşitli değişkenlere göre incelenmesi. Erciyes Illetişim Dergisi, 5(4), 405-421. https://doi.org/ 10.17680/erciyesiletisim.379886

Çiftçi, H. (2018). Üniversite öğrencilerinde sosyal medya bağımlılı̆̆ı. MANAS Sosyal Araştırmalar Dergisi, 7(4).

Çömlekçi, M. F., \& Başol, O. (2019). Gençlerin sosyal medya kullanım amaçları ile sosyal medya bağımlılığı ilişkisinin incelenmesi. Manisa Celal Bayar Üniversitesi Sosyal Bilimler Dergisi, 17(4), 173-188. https://doi.org/10.18026/cbayarsos.525652

Coşkun, R., Altunışık, R., \& Yıldırım, E. (2017). Sosyal Bilimlerde Araştırma Yöntemleri SPSS Uygulamalı. Sakarya Yayıncılı (9th ed.). Baskı, Sakarya.

Dağl1, A., \& Baysal, N. (2016). Yaşam doyumu ölçeğinin Türkçe’ye uyarlanması: Geçerlik ve güvenirlik çalışması. Elektronik Sosyal Bilimler Dergisi, 15(59). https://doi.org/10.17755/ esosder.263229

de Klerk, N., \& Bevan-Dye, A. L. (2014). Free-time management amongst generation Y students. Mediterranean Journal of Social Sciences, 5(21), 11-11. https://doi.org/10.5901/ mjss.2014.v5n21p11

Diener, E. D., Emmons, R. A., Larsen, R. J., \& Griffin, S. (1985). The satisfaction with life scale. Journal of Personality Assessment, 49(1), 71-75. https://doi.org/10.1207/s15327752 jpa4901_13

Grau, S., Kleiser, S., \& Bright, L. (2019). Exploring social media addiction among student Millennials. Qualitative Market Research, 22(2), 200-216. https://doi.org/10.1108/QMR-022017-0058

Griffiths, M. D., \& Kuss, D. (2017). Adolescent social media addiction (revisited). Education and Health, 35(3), 49-52.

Hawi, N. S., \& Samaha, M. (2017). The relations among social media addiction, self-esteem, 
and life satisfaction in university students. Social Science Computer Review, 35(5), 576-586. https://doi.org/10.1177/0894439316660340

Kaas, E. T., \& Artımaç, A. (2017). Free time management, leisure participation and satisfaction in university students. Journal of Educational \& Instructional Studies in the World, 7(4).

Kırtepe, A., \& Yıldırım, E. (2018). Park ve rekreasyon alanlarını kullanan bireylerin boş zaman yönetim düzeylerinin incelenmesi. Turkish Studies, 13, 19. https://doi.org/10.7827/ TurkishStudies.14149

Longstreet, P., \& Brooks, S. (2017). Life satisfaction: A key to managing internet \& social media addiction. Technology in Society, 50, 73-77. https://doi.org/10.1016/j.techsoc.2017. 05.003

Nakaya, N. C. (2015). Internet and Social Media Addiction. Reference Point Press, San Diego.

Sahin, C. (2017). The predictive level of social media addiction for life satisfaction: A study on university students. Turkish Online Journal of Educational Technology, 16(4), 120-125.

Serdar, E., Demirel, D. H., Demirel, M., \& Çakır, V. O. (2017). The relationship between university students' free time management and academic success. The Online Journal of Recreation and Sports, 6(4), 72-82. https://doi.org/10.22282/ojrs.2017.22

Statista. (2021). Retrieved from https://www.statista.com/statistics/617136/digital-populationworldwide

Tutgun-Ünal, A. (2015). Sosyal Medya Bă̆ımlılı̆̆ı: Üniversite Öğrencileri Üzerine Bir Araştırma (Doktora Tezi, Marmara Üniversitesi Sosyal Bilimler Enstitüsü).

Veenhoven, R. (1996). The study of life satisfaction. İçinde; W. E. Saris, R. Veenhoven, A. C. Scherpenzeel, \& B. Bunting (Eds.), A comparative study of satisfaction with life in Europe (pp. 11-48). Budapest: Eotvos University Press.

Wang, W. C. (2019). Exploring the relationship among free-time management, leisure boredom, and internet addiction in undergraduates in Taiwan. Psychological Reports, 122(5), 1651-1665. https://doi.org/10.1177/0033294118789034

Wang, W. C., Kao, C. H., Huan, T. C., \& Wu, C. C. (2011). Free time management contributes to better quality of life: A study of undergraduate students in Taiwan. Journal of Happiness Studies, 12(4), 561-573. https://doi.org/10.1007/s10902-010-9217-7

Yaşartürk, F., Akyüz, H., \& Karataş, İ. (2018). Rekreasyon bölümü öğrencilerinin boş zaman yönetimi ile akademik başarılarını etkileyen örgütsel faktörler arasındaki ilişkinin incelenmesi. Spor Bilimleri Araştırmaları Dergisi, 3(2), 233-243. https://doi.org/10.25307/ jssr.485859

Yeşildal, M., \& Üstünbaş, B. N. (2019). Etkisiz Bir Boş Zaman Yönetimi Sonucu: Sosyal Medya Bağimlılı̆̆ (p. 286). 4th International Health Sciences and Management Conference 
2019, İstanbul.

Yesilyurt, F., \& Solpuk Turhan, N. (2020). Prediction of the time spent on instagram by social media addiction and life satisfaction. Cypriot Journal of Educational Science, 15(2), 208-219. https://doi.org/10.18844/cjes.v15i2.4592

Zivnuska, S., Carlson, J. R., Carlson, D. S., Harris, R. B., \& Harris, K. J. (2019). Social media addiction and social media reactions: The implications for job performance. The Journal of Social Psychology, 159(6), 746-760. https://doi.org/10.1080/00224545.2019. 1578725

\section{Copyright Disclaimer}

Copyright for this article is retained by the author(s), with first publication rights granted to the journal.

This is an open-access article distributed under the terms and conditions of the Creative Commons Attribution license (http://creativecommons.org/licenses/by/3.0/). 